\title{
A Model of Shodaqoh-Based Waste Management
}

\author{
Azis Muslim \\ Yogyakarta Sunan Kalijaga Islamic State University of Indonesia \\ muslimtenan@gmail.com
}

Received: March 23, 2015 Accepted: April 7, 2015

doi:10.5296/emsd.v4i1.7300 URL: http://dx.doi.org/10.5296/emsd.v4i1.7300

\begin{abstract}
The problem of waste has become a big issue and requires a serious management. In some cities, this unsolvable problem results in new problems such as social conflict, damaged environment and disease onset. This research aimed to evaluate the waste management in Pakem, Tamanmartani, Kalasan, Sleman, Yogyakarta. This study was conducted using inductive phenomenological approach. The data collection was conducted using observation, interview, and documentation techniques. Techniques of validating data used were the extension of length of stay with the studied subject, participatory observation, and data testing with triangulation. Technique of analyzing data used was an interactive model of analysis. The result of research showed that firstly, shodaqoh concept could change the community's negative perspective on the presence of waste. Secondly, the waste manager appropriately would not only result in a clean and healthy environment but also improve the community's economy.
\end{abstract}

Keywords: Waste, Waste Management, and Waste Shodaqoh

\section{Introduction}

One of environment problems to always become big issue in nearly all of urban areas is waste problem. Urban economic growth becomes a great attraction to some people to migrate to city. As a result, the number of population increases, the community consumption increases dramatically, and finally the volume of waste also increases (Faizah, 2008).

The waste volume growth in Indonesia, particularly in urban areas, increases dramatically over years. For example, in Yogyakarta city, the volume of waste was reported of $532 \mathrm{~m}^{3}$ per day in 2001, of 1,571 $\mathrm{m}^{3}$ per day in 2007 (Marwati, 2013) and increasing dramatically to $8,435 \mathrm{~m}^{3}$ per day in 2012 (BLH, 2013). The increasing volume of waste not compensated with an environment-friendly management will result in environmental damage and pollution (Kustiah, 2005). Furthermore, an incomprehensive waste management will lead to social problems such 
as mass rage, civil dispute, and blockage of waste final disposal place facility.

Today, most waste management ends up in the final disposal place, thereby making the burden of final disposal place very heavy. It is because not only it takes sufficiently wide land, but also the environmental protection facility is very costly (Syafrudin, 2004). One factor causing so much waste disposed to the final disposal place is no attempt of reducing the volume of waste sincerely from its source.

Theoretically, to deal with the waste problem, a shift of approach is required, from the pipe-end to source approaches (Syafrudin, 2004). The pipe-end approach considering waste as useless material, so that it is only collected, transported, and then disposed to the final container, should be changed into the source one considering waste as 'diamond' that should be sorted and selected, so that it can be processed or sold that can yield money. The primary principle of source approach requires the waste to be sent to final processing place should be sorted by the waste produces themselves.

This source approach cannot be implemented easily, because most people's behavior and perception on the presence of waste is still negative. They still consider waste as residue or remnant not worth of reusing. For that reason, there should be a socialization to change their perception and behavior. The socialization using cultural, environmental, or even religious values is desirable to change the perception and behavior.

Pakem Hamlet is the one located in Tamanmartani Village of Kalasan Sub District of Sleman Regency of Daerah Istimewa Yogyakarta that according to the author's observation has been able to change its community's behavior and perception on the presence of waste. This village change its community's perception and behavior on the presence of waste with religion values. Waste is viewed as a diamond with economic values and reasonable to be endowed to others (shodaqoh). For that reason, it is interesting to study the shodaqoh-based waste management model conducted by the community of Pakem Hamlet of Tamanmartani, Kalasan, Sleman, Daerah Istimewa Yogyakarta, in solving the waste problem. This research will focus on concept, implementation and result of shodaqoh-based waste management.

\section{Problem Solving Framework}

Hartoyo (1998) stated that an ideal waste management requires a special standard to be a clear foundation. Such the standard should be included into a binding rule to individual waste organizers. For that reason, there are at least two standard waste managements used by Indonesia today: Indonesian National Standard Number 19-2454-2002 about the Procedure of Waste Management in Settlement, and RI's Law Number 18 of 2008 about Waste Management.

The Indonesian National Standard Number 19-2454-2002 governs five interrelated aspects. The first is operating technique aspect. Operating technique of waste management is integral and chronologically integrated with continuous order: accommodation, collection, displacement, transportation, disposal/processing. Accommodation is a way of accommodating waste before collected, displaced, transported, and disposed to the final disposal place. The objective is to avoid it from being scattered around and disturbing the 
environment. Collection is the process of picking up the waste from waste accommodation to temporary disposal place. Displacement is to displace the waste collected into transportation vehicle to be carried on to the final disposal place. Transportation is the activity of transporting the waste collected in temporary accommodating place to the final disposal place. The objective is to keep the waste away from the settlement. Final disposal is the place provided to dispose waste resulting from any waste transportation.

The second is organization and management aspect. This aspect has main function in driving and activating the waste management system. The third is costing aspect. It functions to fund the waste management operation from waste source to its final disposal. The fourth is legal aspect. This aspect serves to develop rules related to waste management, for example developing the local regulation governing the basic tariff of cleanliness management. The fifth is public participation. This aspect serves to attract the public involvement as the waste producer in participating in dealing with the problem of waste.

Meanwhile, RI's (Republic of Indonesia's) Law Number 18 of 2008 about Waste Management asserts that the waste management should be conducted comprehensively from upstream to downstream. The management is carried out using 3R principle: reuse, reduce, and recycle. This principle is taken to reduce the waste into zero waste.

To process the waste into zero waste, the sorting and processing process should be conducted starting from the waste source. The waste management starts from the waste piling location or waste producer. The organic waste is separated or sorted from inorganic one. Waste is put into different container by its type. The next processes are collection, displacement, and transportation of the sorted waste in order to keep it away from being remixed for the sake of improving the efficiency of waste processing. In the final stage, in disposal/processing place, the organic waste is processed into compost, while the inorganic one is reused or recycled. Meanwhile the non-reusable or non-recyclable inorganic waste is annihilated by means of burying it.

\section{Method}

This research was taken place in Pakem Hamlet of Tamanmartani, Kalasan, Sleman, Daerah Istimewa Yogyakarta. This research was conducted with phenomenological approach, because it is related to behavior, perception, and human paradigm as the organized object of study in the setting of community interaction in the religious values-based waste management. The data were collected by means of observation, interview, and documentation. Techniques of validating data used were the extension of length of stay with the subject studied, participatory observation, and data testing with triangulation method. Meanwhile the technique of analyzing data used was an interactive model of data analysis from Miles and Huberman (1984).

\section{Research Result}

\subsection{Shodaqoh-Based Waste Management Concept}

The early phenomenon occurring in Pakem Hamlet of Tamanmartani Kalasan Sleman is the community's attitude and behavior with less care of waste presence. It is due to the 
community's misperception on the existence of waste. Waste is considered as useless and non-reusable remnant. It is reasonable that such item is disposed and kept away from the environment surrounding their residence. As Gunandar pointed out in the following quotation:

"Masyarakat seringnya membuang sampah sisa-sisa dari keperluan rumah tangga di sungai atau di kebun-kebun kosong yang ada di sekitar tempat tinggal mereka. Mereka tidak berpikir dampak dari pembuangan sampah itu. Sehingga kebun kosong itu penuh dengan tumpukan sampah dan terlihat kotor dan jorok. Tidak hanya itu, sawah-sawah warga juga banyak dipenuhi tumpukan plastik yang terbawa arus aliran sungai. Para pembuang sampah tidak sadar bahwa hal seperti itu akan mengganggu lingkungan dan merusak sawah petani" ("Community often disposes the domestic waste into river or empty gardens around their residence. They do not think about the effect of such the disposal. The empty garden will be full of waste piling and seems to be dirty and untidy. In addition, the members of community's farms are replete with plastic piling carried on by river stream. The waste disposers do not realize that it will disturb environment and damage the farmers' farm" (Interview with Gunandar on September 07, 2014)).

Furthermore, Gunandar explained that such the condition often provokes conflict between the members of society, despite its vagueness. For example, the garden owner become angry, and speaks up loudly to anyone. The objective is to make those living surrounding the garden offended by his remark. If it is left out continuously, the open conflict may occur.

Another problem occurring as the result of dirty environment is the onset of dengue blood fever disease transmitted by mosquito. Some people of Pakem hamlet are infected with blood fever diseases every year. Lilis Suryani, as the chairwoman of Integrated Service Post (Pos Pelayanan Terpadu = Posyandu) of Pakem Hamlet, stated that on average there are three people infected with blood fever disease annually. She explained further that even her son has ever been infected by this frightening disease (interview with Lilis Suryani on September 11, 2014).

Wrong behavior and misperception of Pakem Hamlet's people on the existence of waste are due to their wrong view on the waste. They consider waste as trivial and unimportant. Such the view is called paradigm. Paradigm can be defined as a set of assumptions and beliefs concerning. To arrive at such the level, an established empirical treatment is required. Paradigm can also be defined as a mental window for a place within which there is a frame that should be proved for its truth because the paradigm proponents have had belief (Salim, 2001). For that reason, the people of Pakem Hamlet's apathy and uncaring to waste is a wrong paradigm phenomenon occurring in almost all of societies. The insensitive perspective of Pakem Hamlet people on the problem of waste in this study is thereafter called old paradigm.

Soema (2010) stated that an individual tends to behave and to act corresponding to the experience he/he sees and hears. From Soema's statement, a conclusion can be drawn that if the environment surrounding and individual's residence teaches that disposing waste haphazardly is a common, it indirectly teaches the one to imitate what has been done. When this habit becomes a take-for-granted belief because it occurs frequently, it will be more difficult to change this old paradigm, as the paradigm of waste has become a take-for-granted assumption. 
Pakem people's apathy to waste is the reflection of an ethic that by Fatah et al (2013) citing Sony Keraf is often called anthropocentrism ethic, the one considering human being as the hub of universal natural system. Human being and his/her interest are considered as very decisive in ecosystem order. Anthropocentric ethnic can also be called as egocentric ethic because this ethic underlies the imperative to do good deed for the self (ego). That individual merit is community merit is a claim considered as legitimate. Egocentric ethic orientation is based on individualism philosophy viewing that individual is a social atom standing independently. Anthropocentrism can also be seen as the philosophical theory stating that moral values and principles only apply to human being. In addition, this ethic is very instrumental in the sense that the relationship between human being and nature is seen limited merely to instrumental relation. Nature is considered as an instrument of human interest. Whenever human being is care of nature, it is done only for the sake of ensuring the human life need rather than considering that the nature has its own value and worth of protecting.

The old paradigm phenomenon occurring in Pakem, the community's ideology, attitude and behavior in treating the existence of waste, is the reflection of egoistic anthropocentric attitude and does not see the nature as an integral part of life fabric in the world. For that reason, such the community's view, attitude, and behavior should be changed so that society sees nature as an integral part of life fabric in the world.

The deep understanding and implementation of Islam religion the community of Pakem Hamlet holds, according to Supriyono, can be an efficacious instrument to change old paradigm. Several religion values deriving from al-Qur'an and Hadits can be reference to change the community's point of view, attitude and behavior. For example, the values contained in Surrah ar-Rum verse 41 stating that "Corruption has appeared throughout the land and sea by [reason of] what the hands of people have earned". This verse can be interpreted that nature is an integral part of life fabric in the world to human being. For that reason, human being should preserve nature. Managing waste appropriately is the part of natural preservation and disposing waste haphazardly means destroying the nature. It means that managing waste appropriately is compulsory, and disposing waste haphazardly is illicit (haram) (interview with Supriyono on October 12, 2014).

Another proposition used to change the people of Pakem Hamlet's point of view, attitude and behavior in treating waste is hadits about shodaqoh (alms) stating that "it is obligatory for any Muslim to endow others everyday". This hadist recorded by Buhori, Muslim, and Nasa'i even becomes the foundation of waste management concept. The question is what can be given as shodaqoh? It is dependent on the point of view, attitude, and behavior of community interpreting it. The people of Pakem Village consider and treat waste as 'diamond'. For that reason, this item can be given as shodaqoh. Furthermore, Supriyono explains the procedure as follows:

a. Domestic wastes are sorted into two: organic and inorganic

b. Inorganic waste is sorted into three: paper, plastic and can 
c. The sorted inorganic wastes are put into bag by its types: paper, plastic, and can in their own houses, while intending to endow. Bismillahirrahmanirrahim I intend to give this item as shodaqoh, hopefully it will be beneficial.

d. After the waste bag sorted by its type at home has been full, the waste owner obligatorily brings it and puts into the proximate waste drum provided by its type.

e. The assigned waste officer picks up the sorted wastes from the waste drum, and put them into village waste accommodation weekly.

f. The waste organizing committee sells the collected waste to the intermediary trader monthly.

g. The money resulting from waste sale is reported to the village and then used for community development and empowerment.

h. What about organic waste? The organic waste is processed into organic fertilizer in each household.

The Pakem Village people's ways of viewing and treating the waste as mentioned above is called new paradigm in this study. In this paradigm, shodaqoh becomes the primary concept in waste management. This concept is appropriate to Pakem Hamlet people, because their strong understanding and implementation of Islamic tenet. Endro Setyo Utomo told that one day the members of community have ever been offered with aid for waste management, but they rejected it because the concept should be changed into waste bank system. Bank is considered as inappropriate, because it is in contradiction with Islam religion (Interview with Endro Setyo Utomo on December 23, 2014).

\subsection{The Implementation of Shodaqoh-based Waste Management}

The first important point to do in waste management implementation is the establishment of institution, namely naming the institution and creating the committee. This institution is called "PERMATA" Independent Waste Organizer. Gunandar stated that there are two reasons of why this institution is named permata (precious stone). Firstly, it is to make the community perceives the waste positively. The community should see and treat the existence of waste as the precious stone that can be traded, just like other precious stones. Secondly, it is to make the community remember this name of institution easily, because PERMATA stands for Produktif (Productive), Elok (Lovely), Rindang (Shady), Maju (Advanced), Tertib (Orderly), and Agamis (Religious) (Interview with Gunandar on September 13, 2014).

The structure of institution committee consists of society leaders existing in Pakem Hamlet such as kepala dusun (head of hamlet), all of Rukun Tetangga (RT) and Rukun Warga (RW) administrators, the head of takmir masjid (mosque leadership), the head of youths, the head of family welfare empowerment (pemberdayaan kesejahteraan keluarga $=\mathrm{PKK}$ ), the head of hamlet community empowerment agency (lembaga pemberdayaan masyarakat dusun = LPMD) and individuals occupying the important roles within the society like muballeg (Islam scholars), police officers, teachers, and lecturers. The reason of including the important figures into this leadership is that they are role models whose behavior can be imitated and can persuade others easily, so that whatever they do, others will imitated it, and whenever they invite others to do something, others will follow. 
Having the waste management institution been established, the first duty of committee is to build the community's awareness of the importance of waste management. Building the community's awareness becomes the primary priority before building on other infrastructures. The reason is that without support from the community, the established institution will be in vain because the community's behavior does not change, and it is difficult to look for support for developing its infrastructure. Here are the attempts taken to build the community's awareness:

\section{a. Routine Pengajian on Thursday Night}

This pengajian (communal Quran learning) is a public pengajian for the people of Pakem Hamlet, Tamanmartani Kalasan that has been conducted for many years, the participants of which are children, teenagers and adult. Through this pengajian, the committee explains that a waste management institution has been established in Pakem hamlet. For that reason, individual Pakem people are required to participate in this program. The forum of pengajian, in addition to explaining the propositions concerning the importance of managing waste and maintaining environment, also explains the procedure of managing the waste appropriately, from classifying waste at household to managing the waste in the final waste accommodation place. Even in the pengajian forum, the simulation of waste management is also conducted for children, with the assumption that if the children understand, the teenagers and adults must understand as well.

b. Field Practice through mass service work

Cleaning the hamlet from inorganic waste dirt is accomplished massively through join service work. This service work (kerja bakti) is organized weekly or monthly, and incidentally. For example, the service work for adult women is held in the first and second weeks every month, the location of which is in each own rukun tetangga, while that for adult men is held in the first week every month, the location of which is defined by the head of hamlet. Meanwhile, incidental service work is held if necessary, for example the one by taking important and historical events, like the one coinciding with the celebration of Kartini Day. By celebrating Kartini Day, the committee holds hamlet cleanliness competition by means of picking up inorganic wastes existing along the road and in the people's garden in Pakem hamlet by dressing Kartini. The wastes the individual participants attain are weighed and the one with the most waste will get special present. In addition, many criteria and many presents are provided; even Campursari music entertainment is also presented to enliven the event. As a result, the community starts to be aware of environment cleanliness, particularly from inorganic waste dirt.

c. Sticker and street banner placement

The sticker about environment cleanliness and waste management procedure is put in every people's house in Pakem hamlet. In addition, the street banner concerning the cleanliness awareness is put in strategic places like the entrance to village, in front of schools, mosque, and graves. The objective is to make the community aware of participating in waste management program. 


\section{Macrothink}

\section{d. Meetings}

The socialization about the waste management is also conducted through meeting forum, whether in RT, RW, mosque leadership, youth or incidental meeting like the meeting concerning idul qurban.

\section{e. Competition}

The socialization through completion is conducted in two ways: holding the competition related to waste management conducted by the committee itself and involving external parties into the competition, for example the clean hamlet competition held by the local government.

Having the community's awareness been build in piecemeal, the waste management committee prepares the construction of infrastructures needed in waste management. They are:

$>$ Waste sorting bag in its source

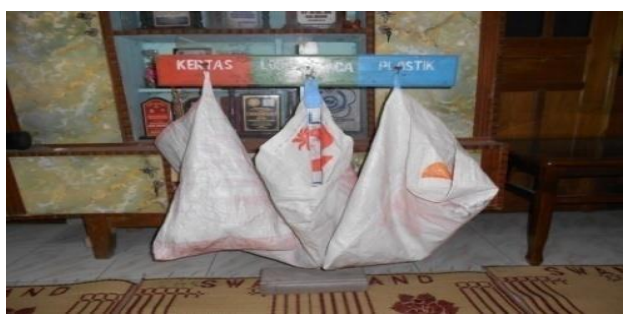

The waste source sorter consists of individual members of family having wastes in their own home. Individual members of family obligatorily have their own waste container consisting of three types: the one for plastic, the one for paper, and the one for can waste. For those having no enough land to dispose their organic waste, it is imperative for them to have additional container for organic waste, composter. This composter is used to accommodate the organic waste to be produced into domestic compost. Everyday, individual members of family sort their inorganic wastes according to the specified classification and put them into the provided bags by spelling the intention of giving shodaqoh.

$>$ The Construction of Temporary Accommodation Place

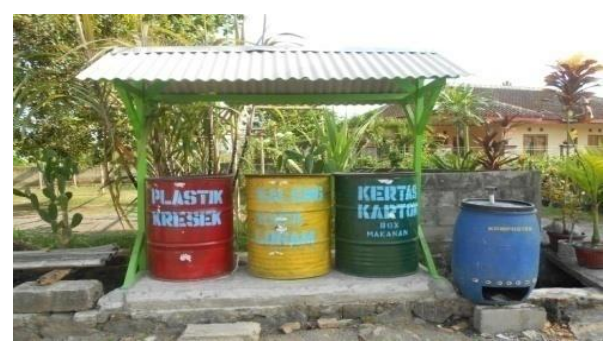

The temporary accommodation place (Tempat Pembuangan Sementara $=$ TPS) constructed adjacent to the people houses is in the form of drum. Each TPS consists of three drums, each of which is for plastic, paper, and can wastes. Each TPS is intended for more than ten houses; in other words, every ten houses have one TPS. This TPS is developed with full participation from each RT. It means that each RT obligatorily develops TPS consistent with the number of 
its people, with the fund deriving from RT cash and effort of the members of RT. The function of TPS is to accommodate the waste from the households located far away from the final accommodation place.

It is the second step in waste management. It means that everyone whose waste bags have been full in the front of their house obligatorily brings and put them into this place.

$>$ The Construction of Final Accommodation Place

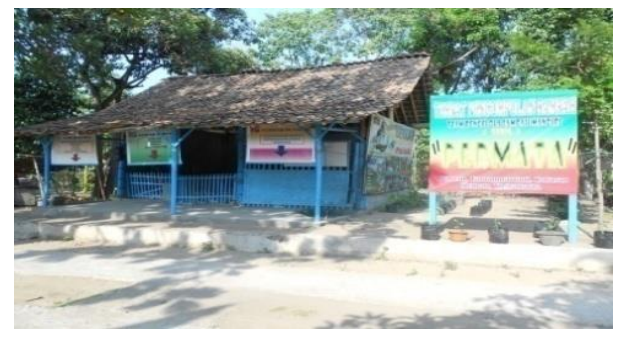

The final accommodation place (Tempat Penampungan Akhir = TPA) is the last place where the wastes are collected. The waste officer picks up the waste from the drums provided in each RT, then put it into TPA. The wastes put into this place have similar type to the ones existing in the waste source. In this place the waste is then sold to intermediary trader (pengepul) with auction system. The result of selling is used for community empowerment in Pakem hamlet, for example for the empowerment of waste recycling group, Makisa fruit processing group, economic empowerment with diverse businesses, road improvement, environment greening, and etc.

\section{The development of profit-sharing system rule}

The profit-sharing rule for waste selling obtained is defined as follows: 50 percents for the waste picking officer, 25 percents for waste organizer, and 25 percents for hamlet institution. The waste picking officer is the youth organization assigned to pick the waste up from the waste drums existing in each RT. The waste officer works once a week to pick the wastes up from the drums except when anyone urges him/her to pick his/her waste up earlier because the drum has been full. Hamlet institution (lembaga dusun) is a hamlet-level organization headed by the head of hamlet (kepala dusun). The utilization of fund by its proportion can be seen in the discussion of result.

\subsection{Result of Shodaqoh-Based Waste Management}

\subsubsection{Direct Result}

The inorganic wastes collected in the final accommodation place of Pakem hamlet cannot be processed entirely by Permata independent waste organizer. It is because of no recycling machine owned. For that reason, the permata independent waste organize only sells the collected and sorted wastes to the intermediary trader by means of entire stock auction system. It means that the intermediary traders (pengepul) willing to pay expensively for the entire stock of wastes without sorting and selection are those who will be accepted to buy the waste. The price per waste item changes over times. For that reason, the transaction is required before selling, rather than subscription system. Here is the summary of selling price per item in the 
first and second sales on April and May 2012:

Table 1. Result of inorganic waste selling per item

\begin{tabular}{|c|c|c|c|c|}
\hline NO & NOTE & TOTAL (UNIT) & UNIT & TOTAL ( IDR) \\
\hline \multirow[t]{11}{*}{1} & The first month selling & & & \\
\hline & Syrup bottle & 144 pieces & IDR 200 / pieces & 28,800 \\
\hline & Soybean ketchup bottle (intact glass) & 9 pieces & IDR 500 / pieces & 4,500 \\
\hline & Plastic bottle such as aqua etc & $56 \mathrm{~kg}$ & IDR $3,000 / \mathrm{kg}$ & 168,000 \\
\hline & Mixed paper & $152 \mathrm{~kg}$ & IDR $800 / \mathrm{kg}$ & 121,600 \\
\hline & Worn-out iron & $31 \mathrm{~kg}$ & IDR $3,000 / \mathrm{kg}$ & 93,000 \\
\hline & Hard plastic (used pail, pot etc) & $5 \mathrm{~kg}$ & IDR $1,000 / \mathrm{kg}$ & 5,000 \\
\hline & Leaf plastic (thin plastic bag, wrapper etc) & $172 \mathrm{~kg}$ & IDR $1,000 / \mathrm{kg}$ & 172,000 \\
\hline & Cardboard paper & $9 \mathrm{~kg}$ & IDR $1,400 / \mathrm{kg}$ & 12,600 \\
\hline & Broken glass in $<3 \mathrm{~m}$ thickness & $220 \mathrm{~kg}$ & IDR $150 / \mathrm{kg}$ & 33,000 \\
\hline & Total first selling & & & 638,500 \\
\hline \multirow[t]{8}{*}{2} & Second month selling & & & \\
\hline & Leaf plastic (thin plastic bag, wrapper etc) & $163 \mathrm{~kg}$ & IDR $650 / \mathrm{kg}$ & 105,950 \\
\hline & Aqua bottle, etc. & $62 \mathrm{~kg}$ & IDR $3,200 / \mathrm{kg}$ & 198,400 \\
\hline & Hard plastic (used pail, pot etc) & $39 \mathrm{~kg}$ & IDR $1,000 / \mathrm{kg}$ & 39,000 \\
\hline & Mixed paper & $179 \mathrm{~kg}$ & IDR $900 / \mathrm{kg}$ & 161,100 \\
\hline & Cardboard paper & $30 \mathrm{~kg}$ & IDR $1,500 / \mathrm{kg}$ & 45,000 \\
\hline & Broken glass in $<3 \mathrm{~m}$ thickness & $298 \mathrm{~kg}$ & IDR $150 / \mathrm{kg}$ & 44,700 \\
\hline & Total first selling & & & 594,150 \\
\hline
\end{tabular}

Source: Document of Permata Waste Selling Result

The table above shows that nearly all of inorganic wastes have economic value when sorted by types. Broken glass, for example, costs IDR 150 per kilogram. Meanwhile, most people dispose this type of item difficultly. It will be dangerous to everyone when it is disposed haphazardly. This dangerous item even can be precious stone when it is treated appropriately. IDR 150 is indeed very small. Everyone largely gives small shodaqoh, doesn't he/she? Remember, something small will be large when it is collected. The table below shows that the result of small waste shodaqoh seems to be large after being collected.

Table 2. Result of Inorganic Waste Sale per month in 2012-2014

\begin{tabular}{|c|l|c|c|c|}
\hline \multirow{2}{*}{ No } & \multirow{2}{*}{ Monthly Selling } & \multicolumn{3}{|c|}{ Total (IDR) } \\
\cline { 3 - 5 } & & 2012 & 2013 & 2014 \\
\hline 1 & January & - & 471.800 & - \\
\hline 2 & February & - & - & 534.000 \\
\hline 3 & March & - & 664.000 & 420.000 \\
\hline 4 & April & 638,500 & 561.150 & 486.500 \\
\hline 5 & May & 594,150 & 510.500 & - \\
\hline
\end{tabular}




\begin{tabular}{|c|c|c|c|c|}
\hline 6 & June & 550,000 & 400.000 & 685.400 \\
\hline 7 & July & 405,000 & 431.000 & 395.000 \\
\hline 8 & August & - & 478.000 & 555.500 \\
\hline 9 & September & 480,000 & 576.000 & 478.000 \\
\hline 10 & October & 583,000 & - & 585.000 \\
\hline 11 & November & 537,000 & 682.400 & 531.500 \\
\hline 12 & December & 472,000 & 443.000 & 443.000 \\
\hline \multicolumn{2}{|r|}{ Total } & 4.259 .650 & 5.217 .850 & 5.113 .900 \\
\hline
\end{tabular}

Source: Document of Permata Waste Selling Result

The table above shows the large economic value of waste disposed for eight months in 2012 if the waste is not managed. Moreover, when it is viewed from the effect of haphazardly waste disposal on natural destruction. On the other hand, the table above shows the decreasing income from April to July in 2012. It is because the wastes of glass, broken glass, glass bottle and pail plastic start to be reduced within the society. The reason is that the people do not always buy glass or broken bottle, or hard plastic like pail every month. For that reason, the income decrease is reasonable. In addition, there is a community movement to reutilize the reusable plastic residues to be reused, for example shopping to the small shop by bringing our own bag, so that the shop does not need to give us new plastic bag.

Meanwhile, the organic waste processed into organic fertilizer is only used for fertilizing personal plants like banana, papaya, and ornament plants today. So wide yards and farms some people of Pakem hamlet have make the product of fertilizer processed using composter or non-composter has not satisfied yet their own need.

Another direct result is clean, healthy and chic environment. From the result of observation, it can be seen that Pakem hamlet environment seems to be clean, with no inorganic wastes scattered around. Tri Setyastomo, as the head of hamlet, states that this hamlet has ever won the first champion of clean and healthy environment competition at regency level. Furthermore, he explained that in the last three years since the waste management began, no member of society is infected with blood fever disease (Interview with Tri Setyastomo on January 11, 2015).

Nowadays, this hamlet is frequently visited by the guests who want to learn about the procedure of managing the waste from ordinary people, officials, students, lecturers, and foreign tourist. With so many visitors, this hamlet is motivated to keep improving itself. The fund for self-improvement activity is taken from the result of selling allocation for the organizer, $25 \%$ of waste selling result. The program utilizing this fund allocation from organizer is intended to realize the chic Pakem hamlet. For that reason, its program focuses on the hamlet greening and beauty. The programs include: 1) planting glodokan pecut, mahogany, banyan, and gayam trees, and etc in hamlet circumference, 2) constructing absorption wells and biopores, 3) constructing the entrance gate to the hamlet, and 4) leasing the cash land for the expansion of omah godhong (leaves house).

\subsubsection{Indirect Result}

The indirect result intended is the blessing obtained from managing the waste. The blessings 
attained from this waste managing practice are:

a. The people's improved economy

As explained above, 25 percents of waste selling result is used for the sake of hamlet. The fund allocated for this hamlet is used for business capital loan without interest for its members of community. Titik Helmi Khoiriyah, as this fund organizer, told that "the fund resulting from waste selling is lent to the members of community who want to open their own business or to expand their business without interest". Furthermore, she told about the success of some people borrowing this fund, as mentioned below:

"Ibu Badariyah, itu sebelah barat jalan ini, pernah dipinjami Rp. 1.000.000,- untuk ternak kambing. Sekarang sudah lunas pinjamannya, kambingnya sudah beranak-pinak, dan sudah ada yang dijual untuk kebutuhan harian. Silahkan dilihat, itu di belakang rumahnya. Ibu Karsini pertama pinjam Rp. 500.000,- untuk usaha pulsa. Setelah lunas pinjam lagi untuk usaha burung kenari. Ibu Jumiyati pinjam untuk membuka usaha laundry pertama Rp. 1.000.000,- setelah lunas pinjam lagi Rp. 500.000,- untuk usaha yang sama. Sekarang pinjam lagi Rp. 1.000.000,- untuk usaha ternak itik katanya. Masih banyak yang lainnya. Ini ada datanya semua, silahkan lihat”.

("Mrs. Badariyah, living in the west of this road, has borrowed IDR.1,000,000 for breeding goat. Now she has paid it completely, and her goats have multiplied and some of them have been sold for her daily need. Look at behind her house, please!. Mrs. Karsini first of all borrowed IDR 500,000 for pulse business. After she paid it completely, she then borrowed again for breeding canary. Mrs Jumiyati borrowed IDR. 1,000,000 firstly for opening her laundry business, after it has been paid completely, she then borrowed IDR 500,000 for the same business. Now she borrows IDR 1,000,000 for duck breeding business. There are still many examples. Here are the data, look at!" (Interview with Titik Helmi Khoiriyah on December 20, 2014)).

Badariyah did not deny when she was asked for confirmation about the truth and the origin of her goat breeding. She told about the origin of her goat breeding as follows:

"Saya dikasih tahu mbakyu saya, katanya saya ditawari pinjaman uang kalau mau usaha. Terus mbakyu saya menyuruh saya ternak kambing, nanti mau dibantu cari rumputnya. Saya mau, terus saya mau pinjam Rp. 500.000,- untuk beli satu kambing. Saya ditertawakan, emangnya saya tidak kasihan, kalau cuma satu kambingnya. Terus saya dipinjami Rp. 1.000.000,- untuk beli dua kambing”.

("I was told by my elder sister that I was offered loan when I want to make a business. Then my sister told me to breed goat, she would help me look for the grass. I was willing to, and then I borrowed IDR 500,000 for buying a goat. The fund organizer even recommended me to buy two goats and finally she lent me IDR 1,000,000" (Interview with Badariyah on December 30, 2014)).

Not only Badariyah feels the improved economy. Tutun who opened her sundry shop feels the same. During observation and interview with Tutun in her house and business site all at once, 
she told about looking for business capital loan easily. Meanwhile, before the presence of waste management activity, it was difficult to look for business capital loan, despite with some interest. This mother of two children who admits that her loan has not been paid completely said that nowadays it is very easy and very convenient to look for loan without collateral (Interview with Tutun on December 30, 2014).

b. The growth of group businesses

As the time progresses, the popularity of Pakem hamlet in managing waste was heard by the local government. It led the Pakem Hamlet to participating in competition activity held by the local government. For example Clean and Healthy Environment (LBS) competition, Environment Shadiness competition, and etc. This hamlet often got satisfactory result like the first champion of LBS competition and environment shadiness at regency level. This satisfactory result gives good reputation to Pakem hamlet that in turn attracts the government's attention. Several units of department invite it to develop a project. For example, Living Environment Office (Kantor Lingkungan Hidup = KLH) of Sleman Regency invites it to build Pakem hamlet into a model hamlet for healthy environment. The Agricultural Service invites it to collaborate in developing organic farm. With these so many collaboration offerings, many group businesses grow in Pakem hamlet. Several groups business growing after the presence of waste management are:

1) Banana farmer group. This group grows in the collaboration with Agricultural Service of Sleman Regency. This group has ever gotten grant in the form of 1,500 seeds of kepok and raja bananas from Agricultural Service.

2) Waste craftsperson group, Markisa fruit processing group, "Plamboyan" female economic empowerment group, "Nusa Indah" female economic empowerment group, and "Aneka Usaha" female economic empowerment group. These groups originally were established with grant resulting from waste selling result. Today they are built under community empowerment office of Sleman Regency. This office helps fund those groups.

3) Goat breeding group. These groups grow due to support from animal husbandry service.

c. The growth of youth creativity

The youth organization in charge of collecting the waste from temporary accommodation place to the final place gets 50 percents of waste selling result. The fund is utilized for developing the youth organization program such as improving skill, organizing the celebration of historical days, and etc. Maudrika Fauzi Alwi stated that in the presence of routine fund income, this youth organization becomes more alive compared with it previously. He stated that "currently the youths need no much consideration to hold an event, because the fund is always available. The youths do not need ask for contribution like they in previous years, because they have had definite income monthly from the waste selling" (Interview with Maudrika Fauzi Alwi on December 18, 2014). Furthermore Alwi (nickname) told that "the youths' creativity and awareness now grow without the adults' compulsion. For example, the youths are currently developing an art the musical instruments and instructors of which are generated by their own fund without adults' contribution. They only ask for advice to adults". Such the youths' creative 
attitude and bravery grow because they have been independent financially.

\section{Discussion of Research Result}

Waste shodaqoh is a new breakthrough in dealing with the acute problem of waste. This concept is an embodiment of religious values the people of Pakem hamlet hold on. The concept of waste shodaqoh implemented well in fact can provide output useful not only to the environment but also to the community's economic improvement. The concept of waste shodaqoh socialized intensively in various ways and occasions can build the community's awareness in seeing and treating the existence of waste. Subsequently, through the awareness growing, the community can develop infrastructures by itself, without asking for help from others. This finding seems to be different from Fatah et al (2013) conducting a research on a theology-based waste management concept. The differences lie in firstly, the members of community in Fatah's study site still reluctantly sorted and selected the waste from source level, so that the officers should work hard to sort and select them in the final accommodation place. Secondly, the infrastructure the organizer provided to the community cannot be utilized maximally. Thirdly, the less intensive communication between waste organizer and the community. Fourthly, the touch of religious values relevant to environment has not become a movement promoted continuously. Fifthly the management of waste bank was still obvious, as seen from the incoming waste being recorded and bought.

On the other hand, the finding of current research also shows the result different from that of Faizah (2008) studying the community-based domestic waste management. The three different important findings are firstly waste processing infrastructures not provided by the community itself but by the government aid. As a result, because the government's grant is not fulfilled, the waste sorting at source level cannot be conducted completely. Secondly, it is difficult to find new administrator to manage the waste. Thirdly, the primary problem found is the difficulty of changing 'disposing waste' into 'utilizing waste' paradigms. The last two findings are due to the community's low awareness of managing the waste. For that reason, appropriate method and material are required to build the community's awareness.

The Pakem hamlet's success in managing the waste comprehensively from upstream to downstream is feasible to be the model for the government in order to encourage other areas to duplicate it. With the concept of shodaqoh-based waste management, Pakem Hamlet can deal with the problem of waste with economic, and health and safety benefits to the members of society and environment. The key to success is the community's awareness. It is line with Wrihatnolo (2007) reminding that before implementing the community empowerment program, the socialization should be conducted first to the prospect beneficiary.

The appropriate process of growing the community's awareness, according to Muslim (2014), is through religion approach, by translating the religious values the prospect beneficiaries hold on into real life practices. This process of growing awareness in fact has been carried out in Pakem hamlet. The religious values related to an imperative to endow (shodaqoh) for every Moslem becomes the basic foundation in waste management, so that it runs effectively and efficiently. 


\section{Macrothink}

The recommendation that should be given in this study is that the government should build the community's awareness continuously and developing so many model projects imitating the waste management model in Pakem hamlet. The "Waste Bank"-based waste management model the government has developed should be confirmed with "Waste Shodaqoh" model. The latter model may be more appropriate recalling that majority Indonesian populations embrace Islam religion.

\section{Conclusion}

The waste management in Pakem hamlet is carried out using shodaqoh concept, in which individual members of society should sort the wastes produced from their own household into two major classifications: organic and inorganic. Inorganic waste is subdivided into three: plastic, paper, and can. The sorted waste is then put into waste bag by its type in the intention of giving shodaqoh. This way is taken as the manifestation of religion tenet's implementation, implementing the Prophet's hadits recommending endowing everyday.

This waste management with shodaqoh concept is implemented well due to support from strong institution. The people occupying in the institutional seats are the community leaders with strong influence in their neighborhood. Through this strong institution, Pakem hamlet can change the community's awareness of the existence of waste. The waste originally treated as residue and remnant that should disposed far away, now has changed. It is treated as precious stone with economic values. For that reason, the waste is managed well. This treatment in fact not only provides a clean, healthy and tidy environment, but also generates economic benefit that can improve the community's income.

\section{References}

Faizah. (2008). Pengelolaan Sampah Rumah Tangga Berbasis Masyarakat: Studi Kasus di Kota Yogyakarta, Thesis, Semarang: Program Magister Ilmu Lingkungan UNDIP.

Fatah, Abdul., Taruno, Tukiman., and Purnaweni, Hartuti. (2013). Konsep Pengelolaan Sampah Berbasis Teologi, Jurnal Ilmu Lingkungan, 11(1), 84-91.

Hartoyo. (1998). Pemanfaatan Pengelolaan Sampah Kota Jawa Timur, Material of National Seminar on Urban Waste Management, Malang: Fakultas Teknik Brawijaya.

Kustiah, Tuti. (2005). Kajian Kebijakan Pengelolaan Sanitasi Berbasis Masyarakat, Bandung: Badan Penelitian dan Pengembangan Departemen Pekerjaan Umum.

Marwati, Siti. (2013). Pengelolaan Sampah Mandiri Berbasis Masyarakat, Report of Service to Society, Yogyakarta: Universitas Negeri Yogyakarta.

Miles, H.B and Huberman, A. M. (1984). Qualitative Data Analysis, a Source Book of New Methods. Beverly Hill: Sage Publication.

Muslim, Azis. (2014). Model Pemberdayaan Ekonomi Masyarakat Miskin Perkotaan Berbasis Tanggung Jawab Sosial Masjid, Dissertation, Surakarta: Program Doktor Penyuluhan Pembangunan/ Pemberdayaan Masyarakat UNS. 


\section{INacrothink}

Environmental Management and Sustainable Development

ISSN 2164-7682

2015, Vol. 4, No. 1

Salim, Agus. (2001). Teori dan Paradigma penelitian Sosial (dari Denzin Guba dan Penerapannya), Yogyakarta: PT Tiara Wacana.

Soema, Soekmana. (2010). Pengantar Ilmu Tekhnik Lingkungan, Seri: Pengelolaan Sampah Perkotaan, Bogor: IPB Press.

Syafrudin. (2004). Model Pengelolaan Sampah Berbasis Masyarakat (Kajian Awal Untuk Kasus Kota Semarang), Paper in Interactive Discussion: Urban Waste Management in Integrated Way, Semarang: Program Magister Ilmu Lingkungan UNDIP.

Wrihatnolo, Randy R., \& Dwidjowijoto, Riant Nugroho. (2007). Manajemen Pemberdayaan: Sebuah Pengantar dan Panduan untuk Pemberdayaan Masyarakat. Jakarta: PT Elex Media Komputindo.

\section{Copyright Disclaimer}

Copyright for this article is retained by the author(s), with first publication rights granted to the journal.

This is an open-access article distributed under the terms and conditions of the Creative Commons Attribution license (http://creativecommons.org/licenses/by/3.0/). 